\title{
Late Cretaceous evolution of the northern Sistan suture zone, eastern Iran: Implications of magnetic fabrics and microstructures in the Bibi Maryam granitoid
}

\author{
Zeinab Etemadkhah*, Mohammad Mahdi Khatib and Mohammad Hossein Zarrinkoub \\ Department of Geology, Birjand University, Birjand, Iran. \\ ${ }^{*}$ Corresponding author.e-mail: z.etemadkhah@birjand.ac.ir
}

\begin{abstract}
Anisotropy of magnetic susceptibility (AMS) survey supported by field and microstructural studies have been applied on the Late Cretaceous Bibi Maryam granitoid (BMG) in the northern Sistan suture zone (SSZ), east of Iran. The BMG is composed of quartzdiorite-tonalite with late granodiorite dykes and stocks that are surrounded by steeply SW-dipping Neh shear zone (NSZ). The magmatic fabrics are characterized by transpressional environment dominated by steep dipping foliations (mean strike: $\mathrm{N} 13^{\circ} \mathrm{W}$ ) and sub-horizontal stretching lineations (mean trend: $167^{\circ}$ ). Based on microstructural studies, it is inferred that these fabrics are related to emplacement and cooling of the pluton and the internal fabrics revealed are evidence of a deformation continuum in the granitoid from magmatic to solid state. Deformation in the region continued even after the BMG had fully crystallized, which led to development of the NW-SE foliations and lineation trend that these fabrics are subparallel with the NSZ. The BMG has emplaced in a transpressional setting that was controlled by a NW-SE stretching direction and supported the model that has proposed the relationship between granitoid emplacement and oblique intra-oceanic subduction of the Neotethys during the Late Cretaceous already recognized in this part of the SSZ.
\end{abstract}

\section{Introduction}

The Late Mesozoic-Cenozoic structural setting of the Sistan suture zone (SSZ) is characterized by overprinting of several tectonic events. Identifying these structures, especially during the Late Cretaceous dissolved, to some extent, by means of the study of granitoid bodies, can be potential tools as strain markers. Plutons record structural elements that are related to their emplacement during the cooling of magma as a short time interval allowing an accurate reconstitution of the tectonic evolution of orogenic belts (Gleizes et al. 1997; Benn et al. 2001). Many studies demonstrate that emplacement can be regarded as syntectonic if the magmatic fabric pattern is compatible with the regional strain field under various geodynamic and kinematic environments, particularly transpressive and extensional regime, such as in Europe (Talbot et al. 2005; Be Mezeme et al. 2007; AntolinTomas et al. 2009; Verner et al. 2009; Turrillot et al. 2011; Plissart et al. 2012; Zak et al. 2012), Iran (Sadeghian et al. 2005; Esmaeily et al. 2007; Ghalamghash et al. 2009; Rasouli et al. 2012), India (Moyen et al. 2003; Mamtani and Greiling 2005; Nagaraju et al. 2008), Americas (Neves et al. 2003; Gebelin et al. 2006; Archanjo et al. 2009; Demartis et al. 2011) and Africa (Ferre et al. 1995; Cecys and Benn 2007; Vegas et al. 2008).

During the Late Cretaceous, several small intrusive bodies have emplaced in the SSZ (Camp and Griffis 1982). The Neh shear zone (NSZ) and its

Keywords. Anisotropy of magnetic susceptibility; transpression; granitoid; Sistan suture zone. 
splay terminations are major structures as a key significance in deforming various crustal domains of the SSZ (figure 1b; Camp and Griffis 1982; Tirrul et al. 1983; Walker et al. 2009; Pang et al. 2012). The Bibi Maryam granitoid (BMG) located in the central part of the NSZ is one of them that have so far remained unexplored from the structural point of view and the tectonic setting of this area at the time of the granitoid emplacement is still debated. The Bibi Maryam body provides a good example of well-established geochronology and geochemical characterization.

This study presents the detailed architecture that enables us to define the internal structure of the granitoid to propose an emplacement model and can serve as an important marker that contributes to the knowledge of deformational history of the SSZ, which is one of the most poorly understood areas of the eastern Iran. To clarify these issues we used the tools of structural study of the BMG, essentially the anisotropy of magnetic susceptibility (AMS) to build up structural patterns, with field and microstructural observations.

\section{Geological context}

\subsection{The Sistan suture zone}

The SSZ is highly complex and marks the closure of a N-S trending branch of narrow arm of Neotethys Ocean (called the Sistan Ocean) in eastern Iran. This was accompanied by the suturing between the structurally coherent Lut and Afghan continental blocks, to the west and east, respectively (Tirrul et al. 1983; figure 1a). The northern SSZ was affected by a variety of intrusive, volcanic, volcanoclastic, and sub-volcanic rocks, which started in the Late Cretaceous and continued until Quaternary (figure 1b; see also Richards et al. 2012). Along the SSZ, widespread outcrops of ophiolite complex mark the boundary between the Lut and Afghan continental blocks. Rifting between the Lut and Afghan blocks led to opening of the Sistan Ocean and started in the Early to Middle Cretaceous (Delaloye and Desmons 1980; Babazadeh and De Wever 2004). The remnants of oceanic lithosphere are mid-Cretaceous in age and likely formed at a mid-ocean ridge setting (Zarrinkoub et al. 2012). Subduction is thought to have started between the Turonian-Maastrichtian (Saccani et al. 2010). Some models emphasized an east-dipping subduction system beneath the Afghan continental block (Camp and Griffis 1982; Tirrul et al. 1983; Saccani et al. 2010), while other models proposed west-dipping (Eftekharnejad 1981) and asymmetric subduction (Arjmandzadeh et al. 2011), but its details remain poorly constrained. During the Late Cretaceous, intra-oceanic subduction in the young and hot Sistan oceanic crust followed by the emplacement of small adakitic granitoids
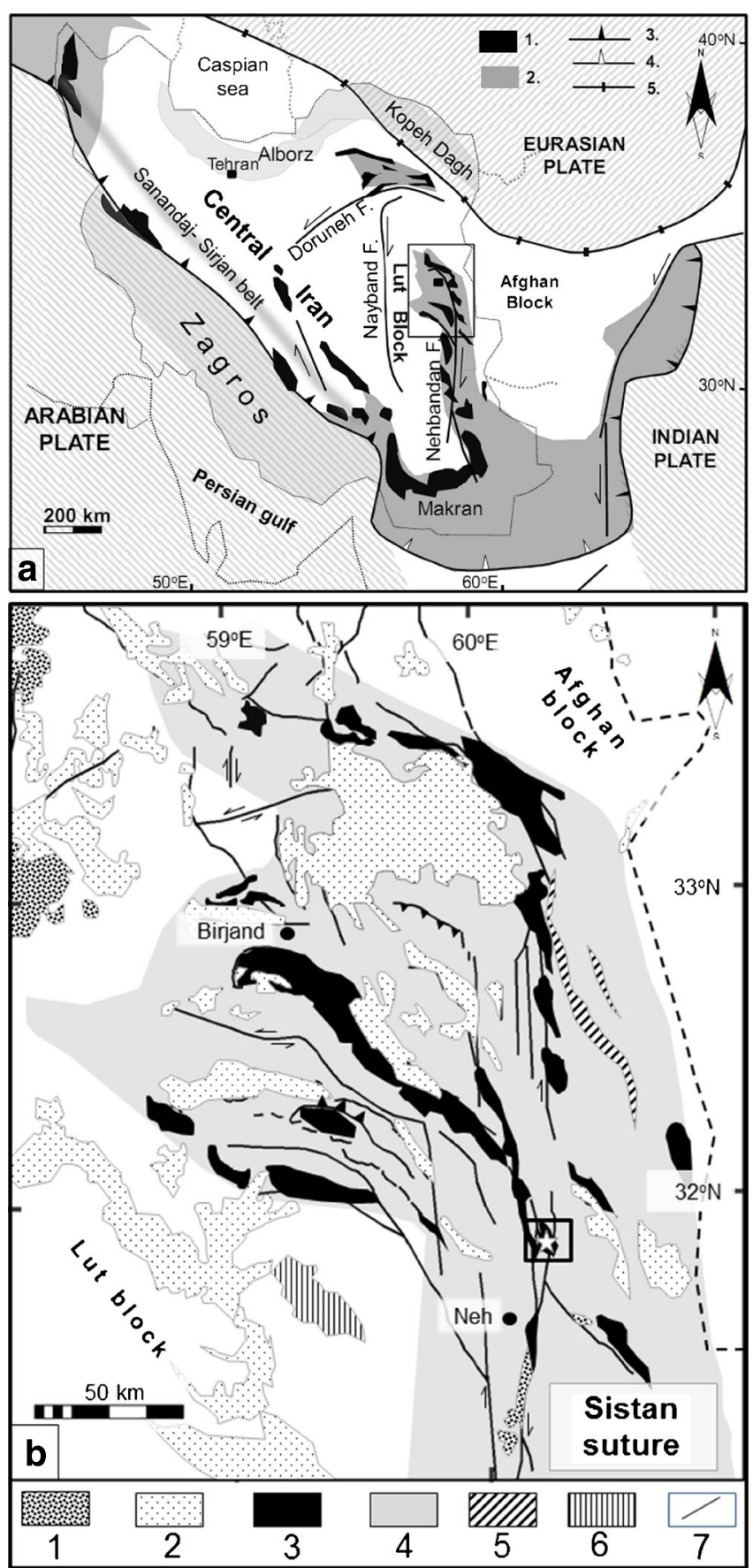

Figure 1. (a) Generalized tectonic map of Iran (after Tirrul et al. 1983 and Berberian and King 1981) and location of the northern SSZ is boxed. (1) Ophiolitic complex, (2) Neo-Tethyan accretionary complex, (3) Neo-Tethyan suture, (4) Paleo-Tethyan suture, (5) Active trench. (b) The northern Sistan suture zone and surrounding areas (modified after Pang et al. 2012). (1) Miocene-Quaternary volcanic rocks, (2) Eocene--Oligocene volcanic rocks, (3) Sistan ophiolitic rocks, (4) Tethyan accretionary complexes, (5) Maastrichtian-Paleocene volcanic rocks, (6) Jurassic granite, and (7) Faults. The study area is boxed. 
( 71-86 Ma) such as Bibi Maryam. The emplacement age of this granitoid has been constrained at $71.5 \pm 0.6 \mathrm{Ma}$ using the Zircon U-Pb method (Zarrinkoub et al. 2011). Early Eocene A-type granites were emplaced in the suture zone (Zarrinkoub et al. 2010). Eocene-Oligocene calc-alkaline volcanic rocks are widespread in the suture zone and to the west in the Lut block, and could have resulted from asthenosphere-lithosphere interaction and convective removal of thickened lithospheric root in a post-collisional setting (Pang et al. 2013). Miocene to Quaternary alkali basalts are mostly associated with active, $\sim \mathrm{N}-\mathrm{S}$ dextral strike-slip systems in the Sistan region, i.e., the NSZ (Walker et al. 2009; Pang et al. 2012). The NSZ has been assigned key significance for the tectonic evolution of eastern Iran and right-lateral shear of $\sim 16 \mathrm{~mm} \mathrm{yr}^{-1}$ accommodated at the present day (Vernant et al. 2004), but the timing of the activity of this shear zone is uncertain and questionable. The splay terminations of NSZ have changed to $\mathrm{E}-\mathrm{W}$ trending with compressional component (figure $1 \mathrm{~b}$ ). The relation between igneous rocks of SSZ and NSZ is important as plutons may provide means of deformation phases and tectonic history that make up an orogenic system.

\subsection{The Bibi Maryam granitoid}

The BMG has a rhomb shape with its long axis oriented NW-SE culminating at $2200 \mathrm{~m}$, thus forming the highest summit of the surrounding rocks (figure 2). This massif is situated in the northern part of the SSZ and adjacent to the dextral NSZ (figure 1b). Fold axes in the country rocks of the $\mathrm{BMG}$ and general trend of NSZ are same as NW-SE (figure 2a).

This body displays contacts with the ophiolitic rocks (figures $2 \mathrm{~b}$ and $3 \mathrm{a}$ ). Along its western border, the granitoid has fault contact with shallowly dipping Oligo-Miocene conglomerate. To the east, it disappears under alluvial sand. The BMG is mainly made up of medium to coarse-grained quartzdiorite-tonalites with medium-grained granodiorites (Mohammadi et al. 2007).

The quartzdiorite-tonalites consist of quartz, plagioclase and biotite and locally amphibole, apatite, and zircon. Quartz, sodium plagioclase, and alkali feldspar are the main minerals and the minors are garnet and apatite in the granodiorite unit. The contact between the granodiorite and quartzdiorite-tonalite is progressive over a few meters and dykes of granodiorite in the quartzdiorite-tonalite demonstrate that the latter is slightly younger than the quartzdioritetonalite. A set of NE-SW trending dykes of granodiorite cut across the massif in western part of the quartzdiorite-tonalite and also affect the nearby country rocks (figure $2 \mathrm{~b}$ ). Observed foliations developed in some areas of the BMG, especially in the southern and south-eastern parts
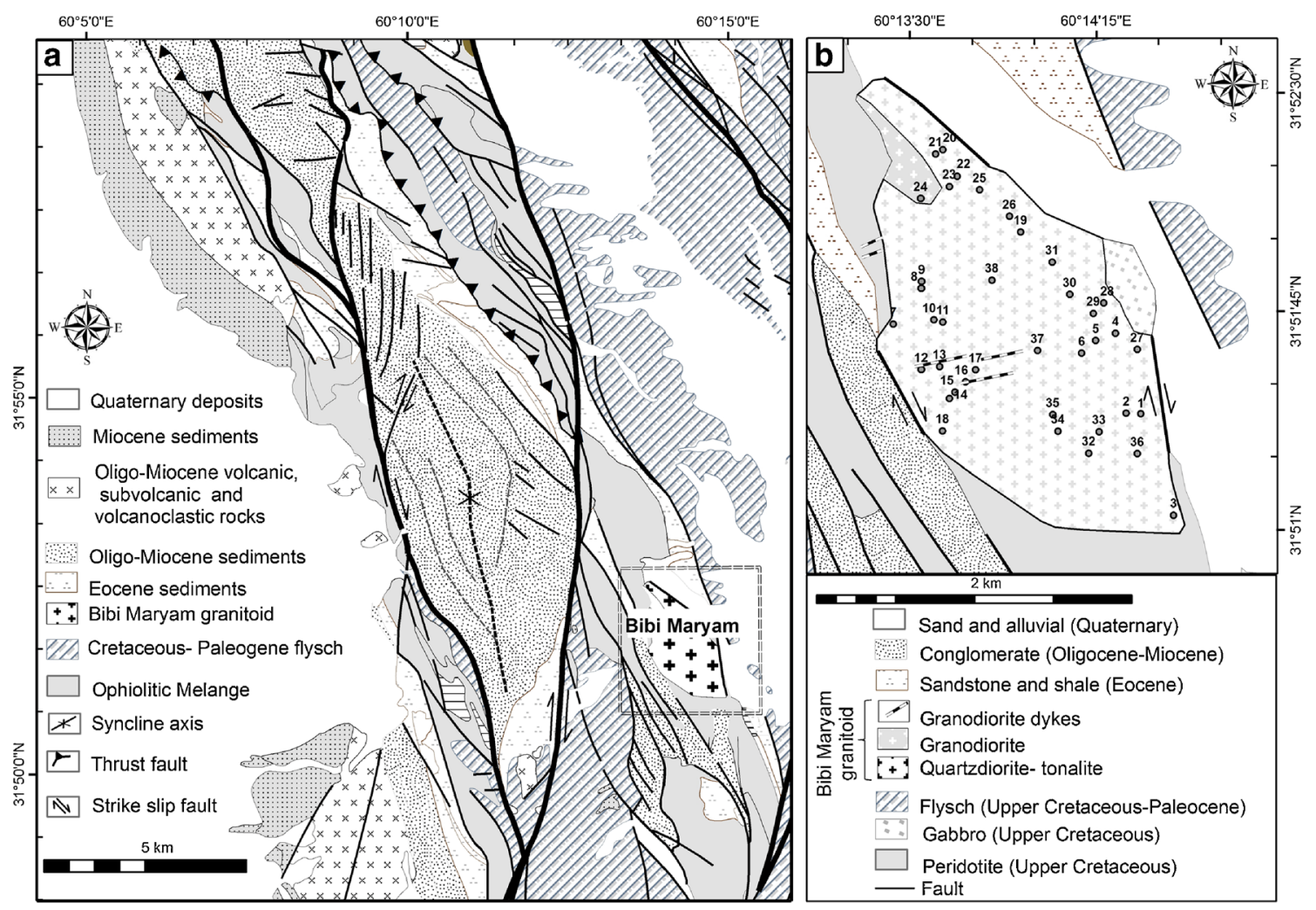

Figure 2. (a) Simplified structural map, the surrounding study area and (b) Bibi Maryam lithologic units map giving sampling stations (38 sites) used for the magnetic fabric study. 
(figure 3b), which are subparallel to the NSZ in this part of the SSZ.

\section{Magnetic study}

\subsection{Data acquisition for AMS measurements}

Samples designated for the AMS investigation were collected from more than 440 oriented specimens from 38 stations within the BMG (figure $2 \mathrm{~b}$ ). At each station, at least two $20 \mathrm{~mm}$ in-diameter oriented cores were drilled with a portable drilling machine. Each drill core was cut into three or four $22 \mathrm{~mm}$-long cylinders, adapted to the sample holder of the susceptometer. AMS and mean susceptibility $\left(K_{m}\right)$ measurements were performed with a MFK1-FA Kappabridge susceptometer of

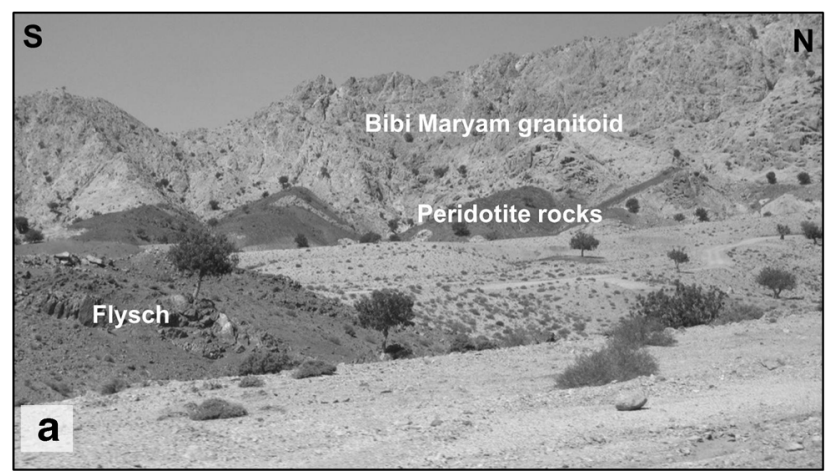

Agico Ltd (Brno, Czech Republic), which has a sensitivity of about $2 \times 10^{-8}$ SI.

The AMS parameters commonly used in magnetic fabric studies (Jelinek 1981; Hrouda 1982; Borradaile and Henry 1997) are represented by the $K_{m}, P^{\prime}$ (corrected anisotropy degree) and $T$ (symmetry of the AMS ellipsoid). The Anisoft program (version 4.2; AGICO, Czech Republic) was used for this calculation. Parameters were defined as follows:

$$
\begin{aligned}
K_{m}= & \left(K_{1}+K_{2}+K_{3}\right) / 3 ; \\
P^{\prime}= & \exp \left\{2 \left[\left(\ln K_{1}-\ln K_{m}\right)^{2}+\left(\ln K_{2}-\ln K_{m}\right)^{2}\right.\right. \\
& \left.\left.+\left(\ln K_{3}-\ln K_{m}\right)^{2}\right]\right\}^{1 / 2} ; \\
T= & 2 \ln \left(K_{2} / K_{3}\right) / \ln \left(K_{1} / K_{3}\right)-1(\text { Jelinek 1981). }
\end{aligned}
$$

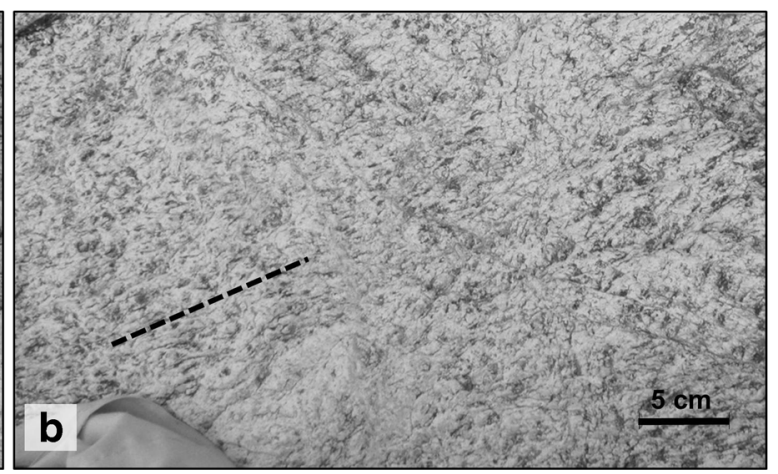

Figure 3. (a) Contact at the southeastern margin of the BMG and (b) NW-SE magmatic foliation in the southeastern margin of the BMG.
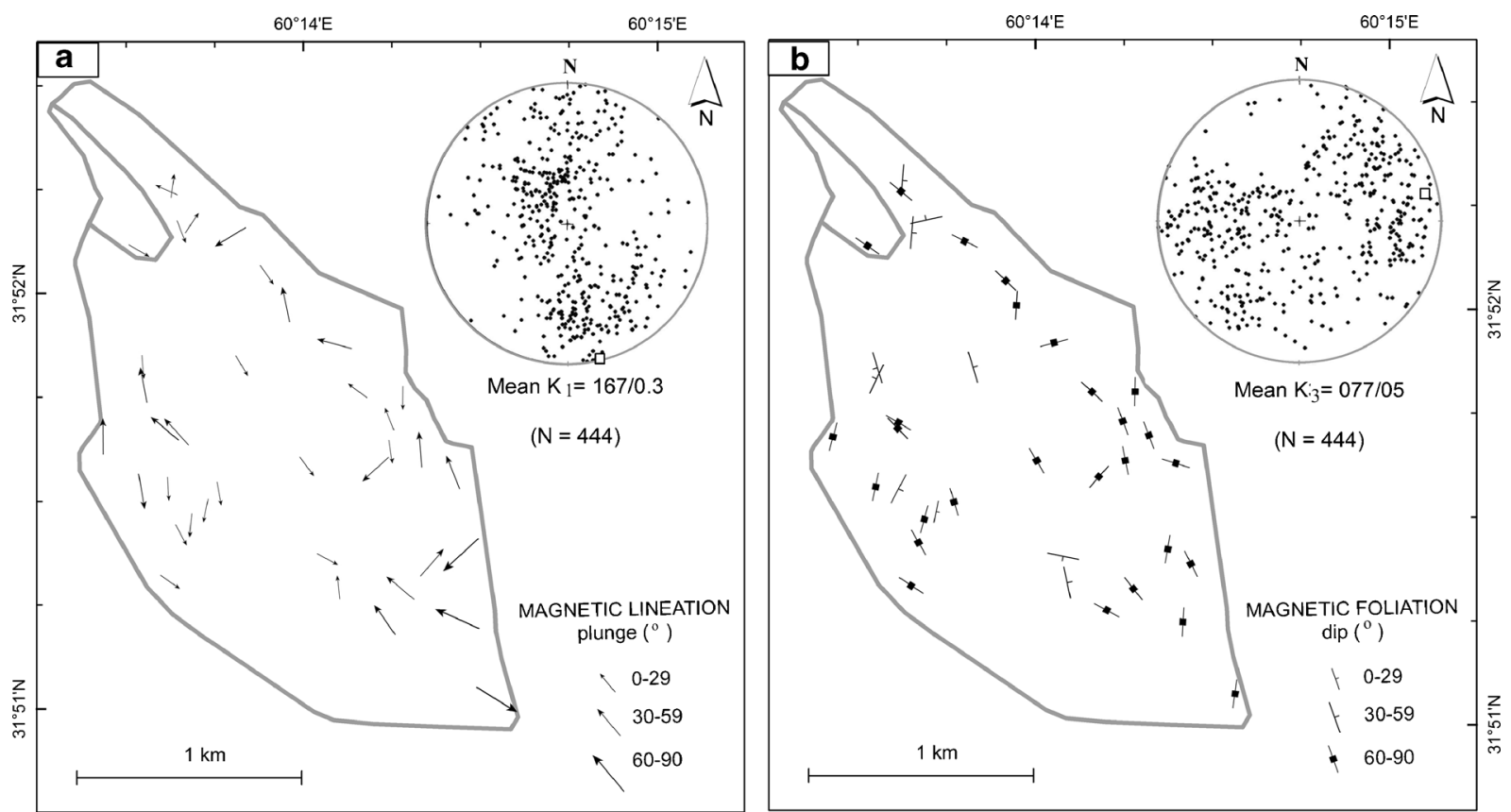

Figure 4. Structural maps of the Bibi Maryam granitoid: (a) Magnetic lineations and corresponding equal-area orientation diagram and (b) magnetic foliations and equal-area orientation diagram of the foliation poles. 
Susceptibility values $K_{1}, K_{2}$, and $K_{3}$ corresponding to the three main axes of the magnetic susceptibility ellipsoid. The magnetic lineation represents the $K_{1}$ axes. $K_{3}$ axes correspond to the magnetic foliation poles determined by planes containing $K_{1}$ and $K_{2}$ axes. These orientation data were used to construct the structural maps of figure 4. All average station magnetic results of the studied rocks are listed in table 1.

\subsection{Magnetic mineralogy and scalar parameters}

The magnetic susceptibility magnitudes $\left(K_{m}\right)$ vary from 24 to $1897 \mu$ SI with an average value of $214 \mu \mathrm{SI}$ (table 1), increasing in magnitude from the granodiorite to the quartzdiorite-tonalite (figure 5a). Such a low susceptibility $(<500 \mu \mathrm{SI})$ is characteristic of paramagnetic granites, which are the main carriers of AMS paramagnetic minerals (Bouchez 1997). High susceptibility magnitudes $(>500 \mu \mathrm{SI})$ are characterized by the presence of ferromagnesian minerals from center towards the south (No.17.32.34) in the BMG, the rest of the samples are controlled by paramagnetic behaviour. This is consistent with the modal compositions of the examined quartzdiorite-tonalites in which biotites are the most important paramagnetic minerals making up 8-10\% of the rock (Mohammadi et al. 2007). In other words, biotite can be considered as the main carrier of magnetic susceptibility in some parts of the granitoid; the mean susceptibility $\left(K_{m}\right)$ map showing the spatial variation of

Table 1. Magnetic data for the Bibi Maryam granitoid.

\begin{tabular}{|c|c|c|c|c|c|c|c|c|}
\hline Site & $n$ & Long. $60^{\circ}+$ & Lat. $31^{\circ}+$ & $K_{m} \mu \mathrm{SI}$ & Lin. az/pl. & $\perp$ Fol. az/pl. & $P^{\prime}$ & $T$ \\
\hline 1 & 18 & $14^{\prime} 28^{\prime \prime}$ & $51^{\prime} 23^{\prime \prime}$ & 107 & $227 / 68$ & $063 / 21$ & 1.053 & -0.143 \\
\hline 2 & 11 & $14^{\prime} 25^{\prime \prime}$ & $51^{\prime} 23^{\prime \prime}$ & 292 & $041 / 59$ & $279 / 17$ & 1.063 & 0.153 \\
\hline 3 & 15 & $14^{\prime} 37^{\prime \prime}$ & $51^{\prime} 02^{\prime \prime}$ & 92 & $121 / 71$ & $277 / 17$ & 1.049 & 0.623 \\
\hline 4 & 16 & $14^{\prime} 22^{\prime \prime}$ & $51^{\prime} 39^{\prime \prime}$ & 90 & $355 / 47$ & $248 / 14$ & 1.035 & -0.195 \\
\hline 5 & 14 & $14^{\prime} 17^{\prime \prime}$ & $51^{\prime} 38^{\prime \prime}$ & 77 & $171 / 11$ & $078 / 16$ & 1.065 & 0.436 \\
\hline 6 & 8 & $14^{\prime} 14^{\prime \prime}$ & $51^{\prime} 35^{\prime \prime}$ & 111 & $227 / 40$ & $131 / 07$ & 1.066 & 0.48 \\
\hline 7 & 17 & $13^{\prime} 28^{\prime \prime}$ & $51^{\prime} 40^{\prime \prime}$ & 113 & $359 / 51$ & $105 / 11$ & 1.064 & 0.008 \\
\hline 8 & 10 & $13^{\prime} 35^{\prime \prime}$ & $51^{\prime} 47^{\prime \prime}$ & 50 & $349 / 42$ & $115 / 33$ & 1.056 & 0.722 \\
\hline 9 & 8 & $13^{\prime} 35^{\prime \prime}$ & $51^{\prime} 49^{\prime \prime}$ & 25 & $175 / 17$ & $072 / 34$ & 1.018 & 0.531 \\
\hline 10 & 12 & $13^{\prime} 38^{\prime \prime}$ & $51^{\prime} 41^{\prime \prime}$ & 210 & $309 / 57$ & $045 / 03$ & 1.066 & -0.12 \\
\hline 11 & 13 & $13^{\prime} 40^{\prime \prime}$ & $51^{\prime} 41^{\prime \prime}$ & 203 & $317 / 41$ & $210 / 18$ & 1.051 & -0.451 \\
\hline 12 & 14 & $13^{\prime} 35^{\prime \prime}$ & $51^{\prime} 31^{\prime \prime}$ & 136 & $170 / 44$ & $282 / 20$ & 1.074 & -0.363 \\
\hline 13 & 13 & $13^{\prime} 40^{\prime \prime}$ & $51^{\prime} 31^{\prime \prime}$ & 243 & $177 / 26$ & $297 / 45$ & 1.098 & -0.448 \\
\hline 14 & 8 & $13^{\prime} 42^{\prime \prime}$ & $51^{\prime} 25^{\prime \prime}$ & 173 & $151 / 11$ & $060 / 05$ & 1.045 & -0.65 \\
\hline 15 & 21 & $13^{\prime} 43^{\prime \prime}$ & $51^{\prime} 26^{\prime \prime}$ & 409 & $185 / 25$ & $285 / 18$ & 1.083 & -0.564 \\
\hline 16 & 9 & $13^{\prime} 46^{\prime \prime}$ & $51^{\prime} 28^{\prime \prime}$ & 107 & $190 / 00$ & $281 / 64$ & 1.058 & 0.521 \\
\hline 17 & 28 & $13^{\prime} 48^{\prime \prime}$ & $51^{\prime} 31^{\prime \prime}$ & 734 & $169 / 12$ & $073 / 24$ & 1.046 & -0.615 \\
\hline 18 & 16 & $13^{\prime} 41^{\prime \prime}$ & $51^{\prime} 18^{\prime \prime}$ & 95 & $124 / 17$ & 033/04 & 1.043 & 0.295 \\
\hline 19 & 9 & $13^{\prime} 58^{\prime \prime}$ & $51^{\prime} 60^{\prime \prime}$ & 89 & $348 / 32$ & $093 / 22$ & 1.093 & 0.708 \\
\hline 20 & 11 & $13^{\prime} 39^{\prime \prime}$ & $52^{\prime} 16^{\prime \prime}$ & 155 & $007 / 02$ & $274 / 45$ & 1.063 & -0.226 \\
\hline 21 & 12 & $13^{\prime} 37^{\prime \prime}$ & $52^{\prime} 15^{\prime \prime}$ & 122 & $293 / 27$ & $039 / 27$ & 1.027 & -0.229 \\
\hline 22 & 12 & $13^{\prime} 43^{\prime \prime}$ & $52^{\prime} 11^{\prime \prime}$ & 55 & $033 / 25$ & $167 / 54$ & 1.053 & 0.302 \\
\hline 23 & 10 & $13^{\prime} 41^{\prime \prime}$ & $52^{\prime} 09^{\prime \prime}$ & 105 & $157 / 16$ & $274 / 56$ & 1.015 & 0.093 \\
\hline 24 & 14 & $13^{\prime} 34^{\prime \prime}$ & $52^{\prime} 06^{\prime \prime}$ & 24 & $120 / 18$ & $214 / 12$ & 1.043 & 0.854 \\
\hline 25 & 7 & $13^{\prime} 48^{\prime \prime}$ & $52^{\prime} 08^{\prime \prime}$ & 79 & $238 / 59$ & $026 / 26$ & 1.032 & 0.509 \\
\hline 26 & 13 & $13^{\prime} 55^{\prime \prime}$ & $52^{\prime} 03^{\prime \prime}$ & 68 & $144 / 18$ & $043 / 29$ & 1.04 & 0.637 \\
\hline 27 & 14 & $14^{\prime} 27^{\prime \prime}$ & $51^{\prime} 36^{\prime \prime}$ & 68 & $337 / 55$ & $197 / 27$ & 1.068 & -0.106 \\
\hline 28 & 10 & $14^{\prime} 19^{\prime \prime}$ & $51^{\prime} 45^{\prime \prime}$ & 68 & $180 / 00$ & $271 / 25$ & 1.066 & -0.213 \\
\hline 29 & 6 & $14^{\prime} 16^{\prime \prime}$ & $51^{\prime} 43^{\prime \prime}$ & 72 & $338 / 10$ & 069/09 & 1.12 & 0.69 \\
\hline 30 & 7 & $14^{\prime} 11^{\prime \prime}$ & $51^{\prime} 47^{\prime \prime}$ & 146 & $306 / 13$ & $042 / 23$ & 1.023 & 0.553 \\
\hline 31 & 6 & $14^{\prime} 06^{\prime \prime}$ & $51^{\prime} 54^{\prime \prime}$ & 63 & $285 / 48$ & $165 / 23$ & 1.096 & 0.582 \\
\hline 32 & 8 & $14^{\prime} 16^{\prime \prime}$ & $51^{\prime} 14^{\prime \prime}$ & 822 & $324 / 52$ & $208 / 18$ & 1.133 & -0.101 \\
\hline 33 & 9 & $14^{\prime} 18^{\prime \prime}$ & $51^{\prime} 19^{\prime \prime}$ & 140 & $310 / 43$ & $051 / 11$ & 1.037 & -0.409 \\
\hline 34 & 9 & $14^{\prime} 09^{\prime \prime}$ & $51^{\prime} 19^{\prime \prime}$ & 1897 & $354 / 09$ & $258 / 33$ & 1.069 & 0.273 \\
\hline 35 & 7 & $14^{\prime} 07^{\prime \prime}$ & $51^{\prime} 22^{\prime \prime}$ & 117 & $118 / 16$ & $011 / 44$ & 1.044 & 0.841 \\
\hline 36 & 11 & $14^{\prime} 28^{\prime \prime}$ & $51^{\prime} 14^{\prime \prime}$ & 162 & $294 / 68$ & $093 / 20$ & 1.049 & 0.237 \\
\hline 37 & 8 & $14^{\prime} 03^{\prime \prime}$ & $51^{\prime} 35^{\prime \prime}$ & 173 & $143 / 15$ & $239 / 22$ & 1.059 & -0.892 \\
\hline 38 & 8 & $13^{\prime} 52^{\prime \prime}$ & $51^{\prime} 49^{\prime \prime}$ & 429 & $149 / 22$ & $253 / 30$ & 1.064 & -0.765 \\
\hline
\end{tabular}

$n$ : number of analysed specimens; $K_{m}$ : mean susceptibility; Lin: azimuth and plunge $\left(^{\circ}\right)$ of $K_{1} ; \perp$ Fol: azimuth and plunge $\left(^{\circ}\right)$ of $K_{3} ; P^{\prime}$ : corrected degree of AMS; $T$ : shape parameter. 

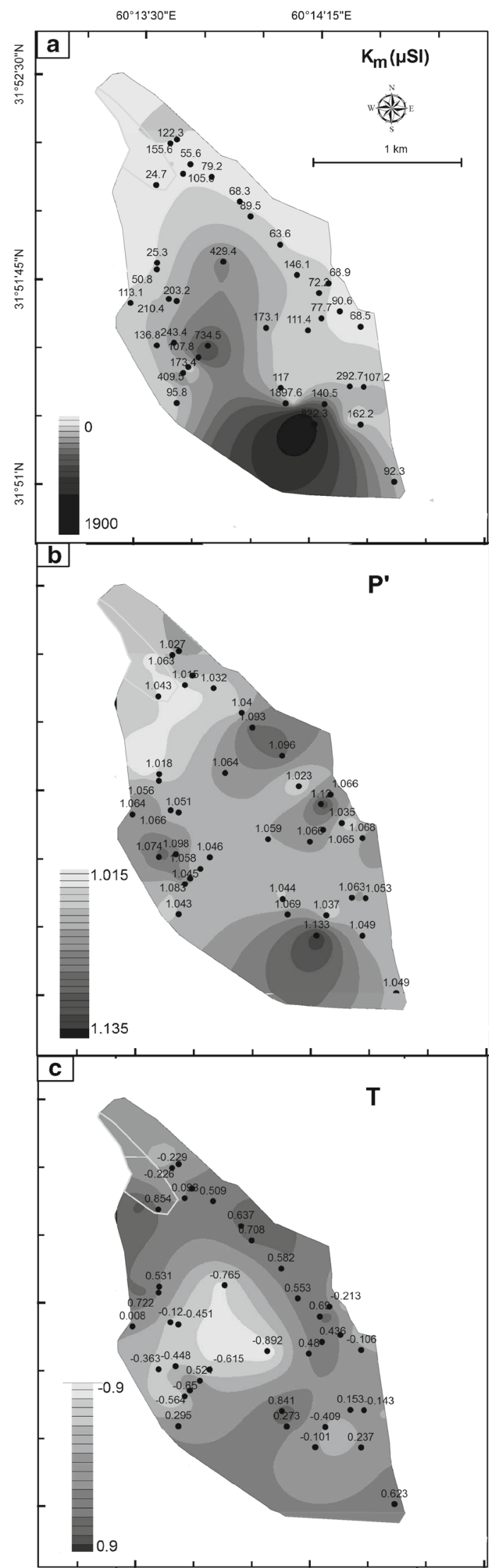

Figure 5. Contour maps of the scalar magnetic parameters from the Bibi Maryam granitoid: (a) Magnetic susceptibility $\left(K_{m}\right)$; (b) corrected anisotropy degree $\left(P^{\prime}\right)$; and (c) shape parameter $(T)$.
$K_{m}$ mainly reflects the biotite content, hence the directional measurements of AMS magnetic fabric reflect the preferential orientation of sheet silicates (Rochette 1987).

The corrected degree of AMS ( $P^{\prime}$ parameter) indicates the intensity of the preferred orientation of the magnetic minerals in the rock (figure 5b). This parameter ranges from 1.015 to 1.133 . In general, the corrected degree of anisotropy is low, with the majority of values below 1.060 and suggesting only moderate deformation. The highest anisotropies correspond mostly to the central southern main body, while the granodiorites have lower anisotropies with respect to mineral preferred orientation in these rocks verified by observation of mineral orientation in thin sections.

Most of the stations have positive $T$ values. Magnetic ellipsoids exhibit both prolate $(\simeq 45 \%$ of the data) and oblate shapes ( $\simeq 55 \%$ of the data) and the $T$ parameter ranges from -0.89 to 0.85

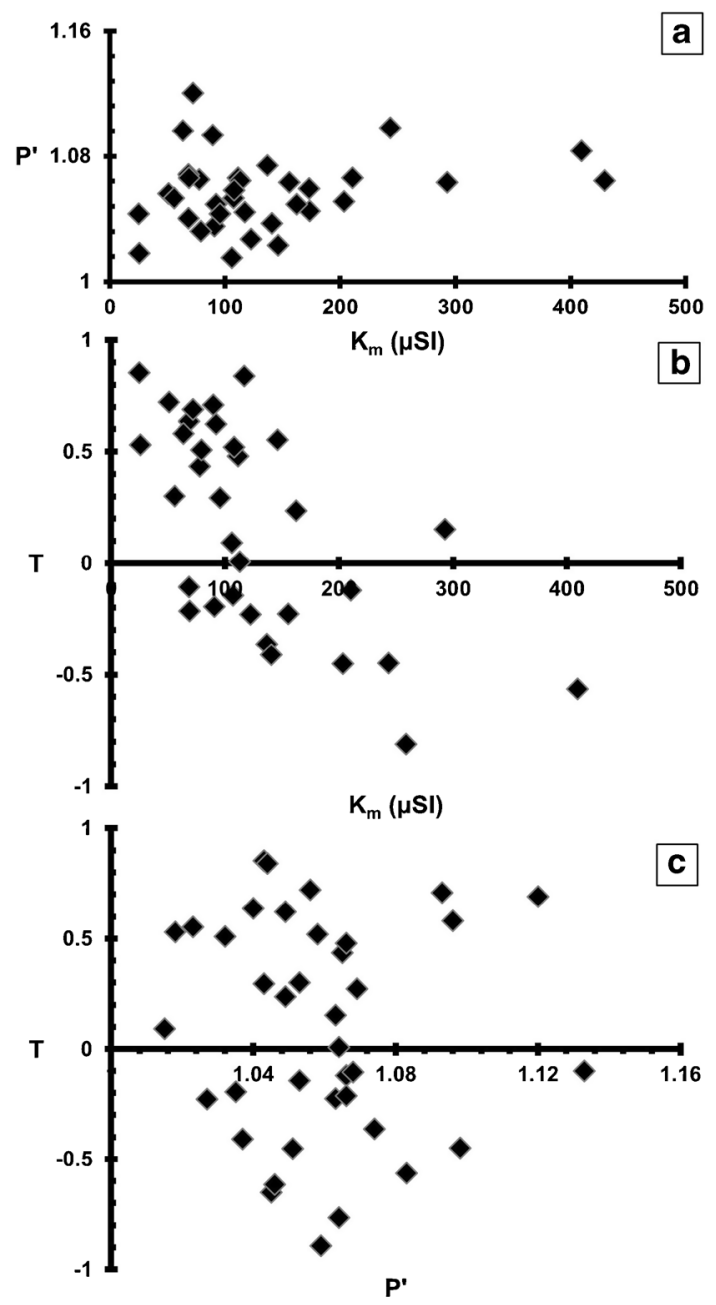

Figure 6. (a) Mean susceptibility $\left(K_{m}\right)$ vs. the degree of anisotropy $\left(P^{\prime}\right)$ for $K_{m}$ values less than $500 \mu \mathrm{SI}$; (b) mean susceptibility $\left(K_{m}\right) v s$. shape parameter $(T)$ for $K_{m}$ values less than $500 \mu \mathrm{SI}$; and (c) the degree of anisotropy $\left(P^{\prime}\right) v s$. shape parameter $(T)$. 
(figure 5c). The central part of the pluton is characterized mostly by prolate fabric ellipsoids. No obvious spatial variations in the mean susceptibility and degree of anisotropy or the shape of the AMS ellipsoid were revealed in the granitoid (figure 6). These results indicate that the values of $T$ and $P^{\prime}$ are not influenced by the petrographic variations observed in the Bibi Maryam massif.

The magnetic foliations mostly strike NW-SE and have steep dips with an average of $85^{\circ}$ to the west (figure $4 \mathrm{~b}$ ). Most of the foliation planes are steep near the margins and strikes generally parallel to the boundaries of the plutonic bodies. On average, lineations have NW-SE trends and shallow plunges to the southeast (mean orientation: $167^{\circ} / 0.3^{\circ}$ ). The southeastern and western parts of the pluton display the highest plunge angles (figure 4a).

\section{Microstructures}

Detailed microstructural observations are required in order to determine whether deformation occurred in the magmatic, weak deformation at high temperature, moderately deformed mostly at high temperature, or significant deformation at low temperature solid-state. Criteria for such distinctions are presented in several studies (Paterson et al. 1989; Bouchez et al. 1992; Passchier and Trouw 1996; Vernon 2000, 2004). The microstructures were studied from thin sections of specimens that have used for the AMS study.

\subsection{Magmatic microstructures}

The magmatic microstructures are developed in the western BMG (figure 8). These microstructures are characterized by euhedral to mostly subhedral quartz grains, which are often free of sub-grain boundaries. Commonly, biotite grains are characterized by the lack of any evidence of solid-state deformation such as undulose extinction or bending. Plagioclase grains exhibit euhedral or subhedral crystal habits. Submagmatic microstructures are evidenced by microfractures in plagioclase crystals filled by microcline or quartz (figure 7a). This substantiates that brittle deformation of plagioclase occurred early when about $30 \%$ of melt was still present (Paterson et al. 1989; Bouchez et al. 1992).

\subsection{Weak deformation at high temperature}

This microstructure occurred under high temperature conditions during magma crystallization
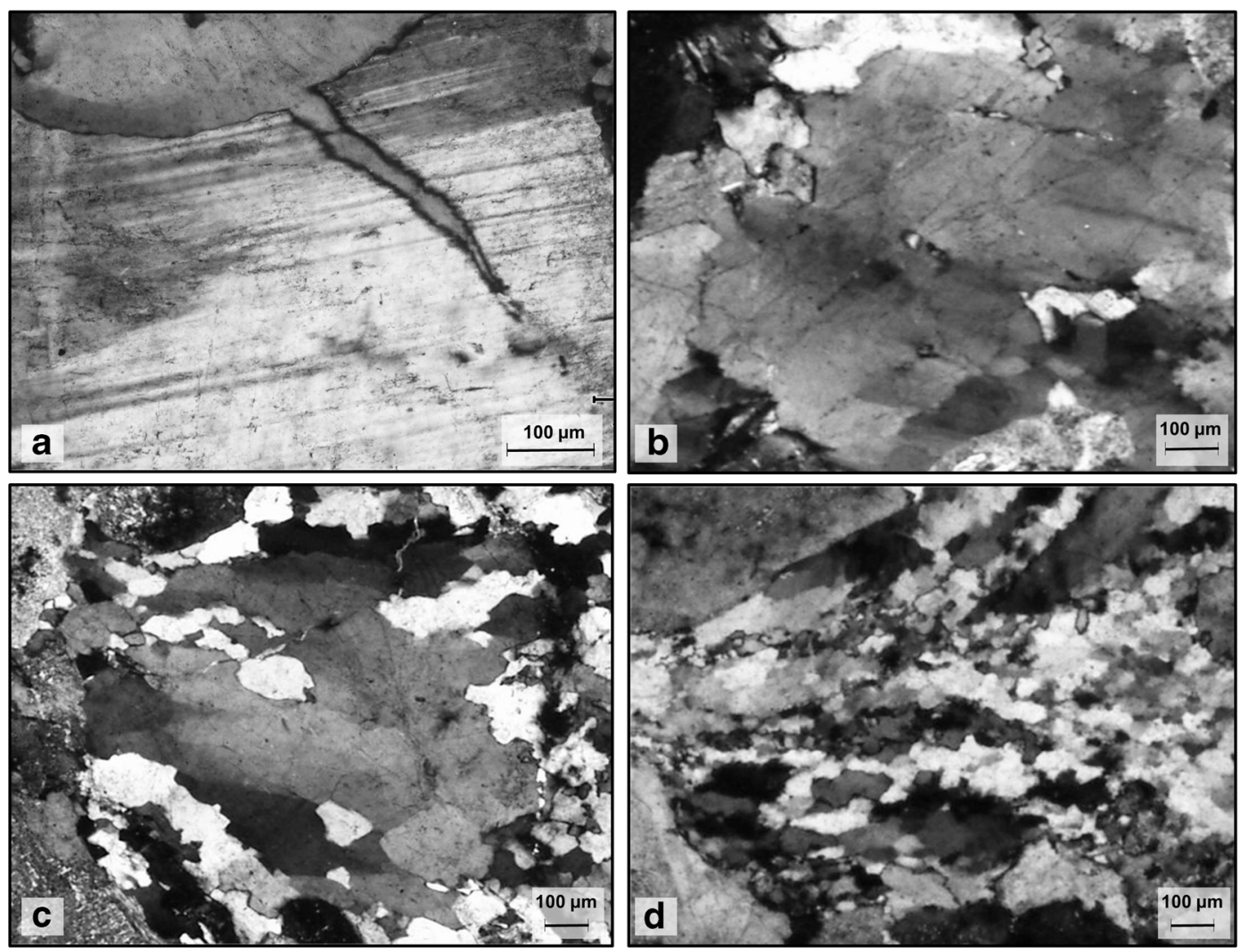

Figure 7. Optical photomicrographs (XPL) illustrating the microstructures of the Bibi Maryam granitoid: (a) Submagmatic microstructure; (b) weak deformation at high temperature; (c) moderately deformed at high temperature; and (d) low temperature solid-state and significant deformation. See text for details. 


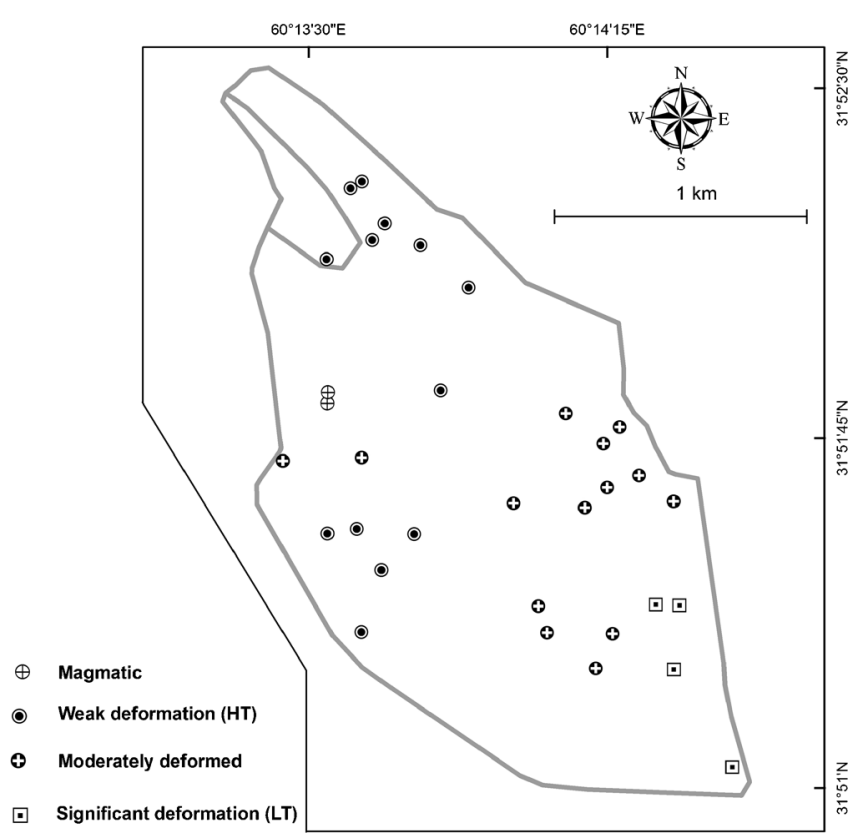

Figure 8. Distribution map of the microstructures within the Bibi Maryam granitoid.

and developed in the transitional rheological state between magmatic and solidus states. This type of microstructure is found at the west and north sides of BMG (figure 8). This part is marked by flame perthite in feldspar and subgrains with a chess board pattern in large quartz grains (figure $7 \mathrm{~b}$ ).

\subsection{Moderately deformed, mostly at high temperature}

This type of microstructure is defined by the presence elongate quartz aggregates, considerable recrystallization into smaller new grains (figure 7c), deformed and kinked biotites, and bent plagioclases. This microstructure is documented in the BMG (figure 8).

\subsection{Low temperature solid-state and significant deformation}

Deformation under low temperature solid-state conditions occurred locally in the southeastern margin of the BMG (figure 8). This microstructure is characterized by strongly recrystallized quartz grains organized in ribbons (figure $7 \mathrm{~d}$ ). Biotites are intensely deformed and feldspar often displays intense undulose extinction.

\section{Discussion}

\subsection{Fabric pattern of the Bibi Maryam granitoid and field observations}

Some samples are characterized by a low susceptibility and are caused by a majority of paramagnetic samples in the BMG; other samples have indicated a ferromagnetic behaviour. AMS ellipsoids are mostly oblate with gently plunging long axes (lineations). High degrees of anisotropy $\left(P^{\prime}\right.$ parameter) concentrate on most parts of the margins $\left(P^{\prime}>1.06\right)$, while the central parts have lower $P^{\prime}$ values (figure $5 \mathrm{~b}$ ). The relatively higher degree of $P^{\prime}$ towards central southern contact indicates a close correlation between the increase of AMS values and the intensity of deformation towards the sheared margins. This parameter becomes stronger towards the east to south-eastern margins and central southern contact, which is consistent with the sub-solidus mylonitic deformation (figure 8), whereas the central part of the intrusion yields a very low degree of anisotropy. Maximum values of $P^{\prime}$ are consistent with higher deformation and lower temperature microstructures, where microstructure is characterized by strongly recrystallized quartz grains organized in ribbons.

The magmatic fabrics are defined as magmatic foliations and lineations formed during (magmatic microstructures) or just after crystallization (high-temperature solid-state microstructures) in the BMG, which mainly correspond to preferred orientation of biotite. Steeply dipping foliations are associated with shallowly plunging magnetic lineations. The lineation trends are generally subparallel to the foliation strikes. The BMG has a good correlation between field structures (foliations and lineations) and magnetic fabrics. In addition, magnetic fabrics of the granitoid show a good correlation with the trend of regional structures of country rocks (figures $1 \mathrm{~b}$ and $2 \mathrm{a}$ ). There are continuities from magmatic to low temperature solid-state generally showing the same orientations in the BMG.

More specifically, the magnetic lineations provide excellent markers of the regional strain field as stretching direction during emplacement and

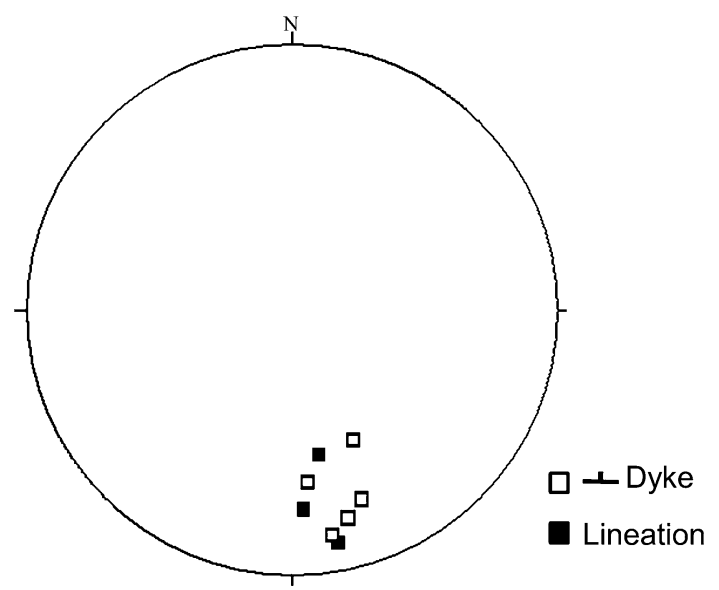

Figure 9. Equal-area diagram showing the relationship between the poles to the granodiorite dykes and the direction of lineations in the quartzdiorite-tonalites surrounding these dykes in the western Bibi Maryam granitoid. For the locations, see figure 2. 
cooling (Bouchez 1997; Saint-Blanquat and Tikoff 1997; Benn et al. 2001). Therefore, the AMS and microstructural data presented in this study was recorded NW-SE stretching regime.

This interpretation is strongly supported by the granodiorite dykes that cross-cut the west of Bibi Maryam massif, perpendicular to the magmatic lineations (figure 9). The structural and kinematic patterns of the granodiorite dykes are consistent with the stretching direction proposed for the quartzdiorite-tonalites. Since the granodiorites are younger than the quartzdiorite-tonalites, the occurrences of NW-SE trending lineations in both units indicate that the regional extension continued during the emplacement and crystallization of the Bibi Maryam complex. Generally, the stretching lineation trend and foliation strike mostly parallel to the long axis of the granitoid. The elongated shape of the massif and foliation strikes generally parallel to the NSZ. Evidences such as the presence of both magmatic and solidstate deformation features and parallel or subparallel magmatic and high-temperature solid-state foliations represent that the NSZ was active during and after complete crystallization of magma. Activation of the NSZ indicates that magma was channelled along the shear zone and therefore the NSZ was active at least since the Late Cretaceous.

\subsection{Interpretation of the magnetic fabrics in the regional tectonic framework}

Based on this work data, emplacement of the BMG was contemporary with NE-SW (in present day coordinates) shortening and NW-SE stretching, consistent with the attitude of magmatic fabrics. Moreover, subhorizontal lineations on steeply dipping foliation planes agree with a wrenchdominated transpressional regime (Tikoff and Greene 1997). Therefore, the intrusion of Bibi Maryam occurred during combined NE-SW compressional and dextral strike-slip movement at least in the later episodes of intrusion, when magma was cooling.

Knowledge of tectonic evolution in the SSZ during the Late Cretaceous is not enough, but the petrological and geochemical data call for adakitic granitoids that formed in an island arc environment (Mohammadi et al. 2007). Therefore, it is assumed that magma stretching took place during granitoid emplacement in an island arc setting resulting from the oblique subduction of the Neotethys during the Late Cretaceous and the right-lateral displacement between the Lut and Afghan continental blocks (figure 10a and b). This scenario led to formation of a transpressional framework with major strike slip faults, the transpression caused extensive NW-trending folds in a Early to Middle Cretaceous (>110-86 Ma)

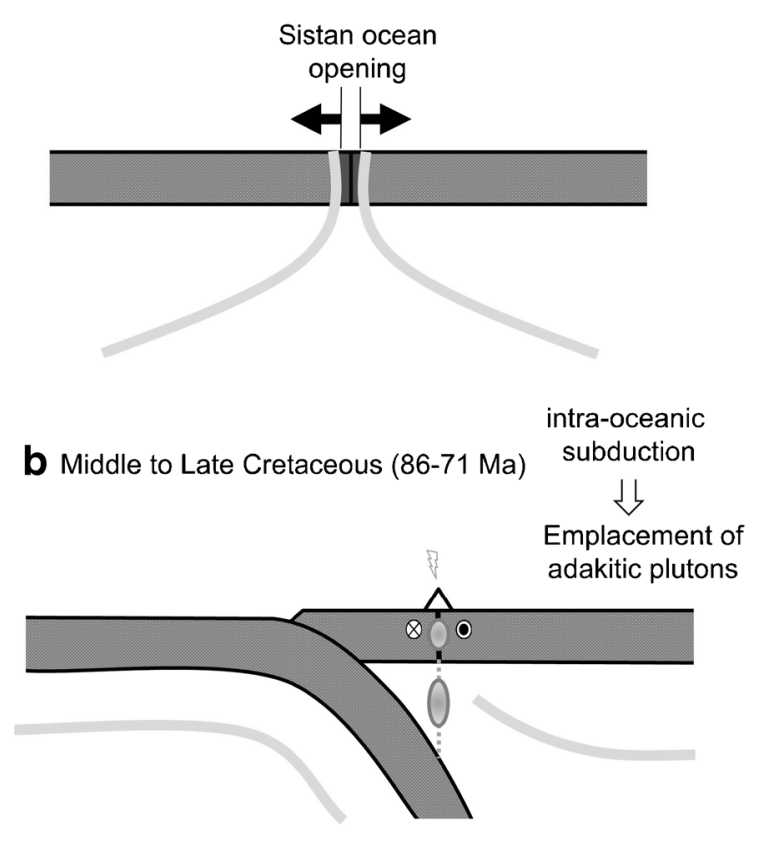

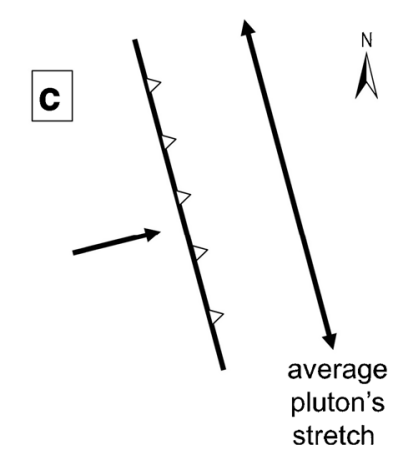

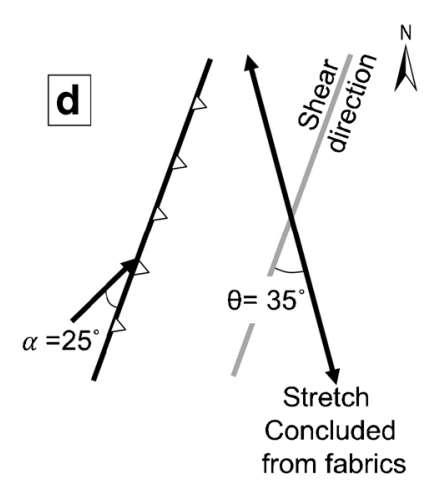

Figure 10. Geodynamic reconstruction around Bibi Maryam. Cross-sections for (a) Early to Middle Cretaceous; (b) Middle to Late Cretaceous. Possible kinematics at the eastern boundary of the Sistan suture zone; (c) for a slip vector perpendicular to the boundary and pure shear deformation during emplacement of the plutons; (d) for a transpression: slip vector oblique to plate boundary; $\alpha$ and $\theta$ are from the analysis of Tikoff and Teyssier (1994) $(\theta=$ angle between stretching axis and the plate boundary, $\alpha=$ angle between the slip vector and the plate boundary). 
the country rocks during the Late Cretaceous to Oligocene.

According to the analysis of Benn et al. (2001), two models are proposed to interpret fabric data. The first one considers that the overall elongation of the plutons results from pure flattening due to arc perpendicular shortening (figure 10c). A second kinematic model calls for emplacement and crystallization undergoing wrench dominated transpression (figure 10d).

Although, there is a lack of data for widespread strains within the country rocks, geological and structural evidences suggest that the transpressional environment dominated throughout the SSZ (Tirrul et al. 1983; Freund 1970). Priority is to consider that the plutons were emplaced under transpression in the SSZ.

In the transpressive model of the region, the relative motion plate results in a combination of dextral simple shearing parallel to the plate boundary and contraction nearly perpendicular to this plate boundary. Many field studies examining wrench-dominated transpression (e.g., Fossen and Tikoff 1993; Tikoff and Greene 1997; Czeck and Hudleston 2003; Iacopini et al. 2008) may have happened upon examples where the convergence angle was close to $20^{\circ}$.

Accepting $\theta=35^{\circ}$, a maximum value argued by Tikoff and Teyssier (1994), for wrench-dominated transpression that considers $\sim 20 \%$ of slip partitioned on strike-slip faults. Since the magnetic lineations trending $\sim 165^{\circ}\left(345^{\circ}\right)$ in the studied granitoid indicate an important component of stretching associated with regional transpression at $\sim 71.5 \mathrm{Ma}$, this gives $\sim 200^{\circ}\left(020^{\circ}\right)$ for the plate boundary strike and $\sim 225^{\circ}\left(045^{\circ}\right)$ for the azimuth of the slip vector between Afghan and Lut microplates (figure 10d; with reference to the present geographic configuration).

\section{Conclusions}

The NW-SE trending granitoid complex of Bibi Maryam that has been affected by wrench faults was emplaced during the Late Cretaceous within a dextral oblique-slip context. Steeply dipping foliations and subhorizontal lineations as the results of AMS data help to clarify the impact of wrench faults on the internal fabric of granitoid. Microstructural studies have demonstrated a close temporal relationship between emplacement, crystallization, and regional strikeslip shearing. These deformation processes have occurred during magmatic and post-magmatic under high, moderate and low-temperature conditions. These results indicate that emplacement of the BMG is coeval with NE-SW shortening and NW-SE extension direction, parallel to the trend of the NSZ during oblique intra-oceanic subduction of the Neotethys in the Late Cretaceous.

\section{Acknowledgement}

The magnetic laboratory of Shahrood University, where AMS measurements have been performed is gratefully acknowledged.

\section{References}

Antolin-Tomas B, Roman-Berdiel T, Casas-Sainz A, Gil-Pena I, Oliva B and Soto R 2009 Structural and magnetic fabric study of the Marimanha granite (Axial zone of the Pyrenees); Int. J. Earth Sci. 98 427-441.

Archanjo C J, Launeau P M, Hollanda H B M and Liu D 2009 Scattering of magnetic fabrics in the Cambrian alkaline granite of Meruoca (Ceará State, northeastern Brazil); Int. J. Earth Sci. 98(8) 1793-1807.

Arjmandzadeh R, Karimpour M H, Mazaheri S A, Santos J F, Medina J M and Homam S M 2011 Sr-Nd isotope geochemistry and petrogenesis of the Chah-Shaljami granitoids (Lut block, eastern Iran); J. Asian Earth Sci $4 \mathbf{1}$ 283-296.

Babazadeh S A and De Wever P 2004 Early Cretaceous radiolarian assemblages from radiolarites in the Sistan Suture (eastern Iran); Geodiversitas 26(2) 185-206.

Be Mezeme E, Faure M, Chen Y, Cocherie A and Talbot J Y 2007 Structural, AMS and geochronological study of a laccolith emplaced during Late Variscan orogenic extension: The Rocles pluton (SE French Massif Central); Int. J. Earth Sci. 96 215-228.

Benn K, Paterson S R, Lund S P, Pignotta G S and Kruse S 2001 Magmatic fabrics in batholiths as markers of regional strains and plate kinematics: Example of the Cretaceous Mt. Stuart batholith; Phys. Chem. Earth 26 343-354.

Berberian M and King G C 1981 Towards a paleogeography and tectonic evolution of Iran; Can. J. Earth Sci. 18 $210-265$.

Borradaile G J and Henry B 1997 Tectonic applications of magnetic susceptibility and its anisotropy; Earth Sci. Rev. 42 9-93.

Bouchez J L 1997 Granite is never isotropic: An introduction to AMS studies of granitic rocks; In: Granite: From Segregation of Melt to Emplacement Fabrics (eds) Bouchez J L, Hutton D H W and Stephens W E, Kluwer Academic Publishers, Dordrecht, pp. 95-112.

Bouchez J L, Delas C, Gleizes G, Nedelec A and Cuney M 1992 Submagmatic microfractures in granites; Geology 20 35-38.

Camp V E and Griffis R J 1982 Character, genesis and tectonic setting of igneous rocks in the Sistan suture zone, eastern Iran; Lithos 15 221-239.

Cecys A and Benn K 2007 Emplacement and deformation of the ca. $1.45 \mathrm{Ga}$ Karlshamn granitoid pluton, southeastern Sweden, during ENE-WSW Danopolonian shortening; Int. J. Earth Sci. 96 397-414.

Czeck D M and Hudleston P J 2003 Testing models for obliquely plunging lineations in transpression: A natural example and theoretical discussion; J. Struct. Geol. 25 959-982.

Delaloye M and Desmons J 1980 Ophiolites and melange terranes in Iran: A geochronological study and its paleotectonic implications; Tectonophys. 68 83-111. 
Demartis M, Pinotti L P, Coniglio J E, D'Eramo F J, Tubía J M, Aragón E and Insúa L A A 2011 Ascent and emplacement of pegmatitic melts in a major reverse shear zone (Sierras de Córdoba, Argentina); J. Struct. Geol. 33 1334-1346.

Eftekharnejad J 1981 Tectonic division of Iran with respect to sedimentary basins; J. Iran. Petrol. Soci. 82 19-28 (in Farsi).

Esmaeily D, Bouchez J L and Siqueira R 2007 Magnetic fabrics and microstructures of the Shah Kuh Jurassic granite pluton (Lut block, eastern Iran) and geodynamic inference; Tectonophys. 439 149-170.

Ferre E, Gleizes G, Bouchez J L and Nnabo P N 1995 Internal fabric and strike-slip emplacement of the PanAfrican granite of Solli Hills, northern Nigeria; Tectonics 14 1205-1219.

Fossen H and Tikoff B 1993 The deformation matrix for simultaneous simple shearing, pure shearing, and volume change, and its application to transpression/transtension tectonics; J. Struct. Geol. 15 413-422.

Freund R 1970 Rotation of strike-slip faults in Sistan, southeast Iran; J. Geol. 78 188-200.

Gebelin A, Martelet G, Chen Y, Brunel M and Faure M 2006 Structure of Late Variscan Millevaches leucogranite massif in the French massif central: AMS and gravity modeling results; J. Struct. Geol. 28 148-169.

Ghalamghash J, Nédéléc A, Bellon H, Vosoughi Abedini M and Bouchez J L 2009 The Urumieh plutonic complex (NW Iran): A record of the geodynamic evolution of the Sanandaj-Sirjan zone during Cretaceous times - Part I: Petrogenesis and K/Ar dating; J. Asian Earth Sci. 35 401-415.

Gleizes G, Leblanc D and Bouchez J L 1997 Variscan granites of the Pyrenees revisited: Their role as syntectonic markers of the orogeny; Terra Nova 9 38-41.

Hrouda F 1982 Magnetic anisotropy of rocks and its application in geology and geophysics; Geophys. Surv. 5 $37-82$.

Iacopini D, Carosi R, Montomoli C and Passchier C W 2008 Strain analysis and vorticity of flow in the Northern Sardinian Variscan Belt: Recognition of partioned oblique deformation event; Tectonophys. 446 77-96.

Jelinek V 1981 Characterization of the magnetic fabric of rocks; Tectonophys. 79 563-567.

Mamtani M A and Greiling R O 2005 Granite emplacement and its relation with regional deformation in the Aravalli Mountain Belt (India): Inferences from magnetic fabric; J. Struct. Geol. 27 2008-2029.

Mohammadi S S, Vosoughy Abdini M, Pourmoafi M, Emami M H and Khatib M M 2007 Petrography, geochemistry, genesis and tectonic setting of Bibi Maryam granitoid (Afzal Abad-Nehbandan); Geol. Surv. Iran, Geosci. 63 60-71.

Moyen J F, Nédélec A and Jayananda M 2003 Syntectonic granite emplacement at different structural levels: The Closepet granite, south India; J. Struct. Geol. 25 611-631.

Nagaraju J, Chetty T R K, Vara Prasad G S and Patil S K 2008 Transpressional tectonic setting during the emplacement of Pasupugallu gabbro pluton, western margin of Eastern Ghats Mobile Belt, India: Evidence from AMS fabrics; Precamb. Res. 162 86-101.

Neves S P, Araujo A, Correia P and Mariano G 2003 Magnetic fabrics in the Cabanas Granite (NE Brazil): Interplay between emplacement and regional fabrics in a dextral transpressive regime; J. Struct. Geol. 25 441-453.

Pang K N, Chung S L, Zarrinkoub M H, Khatib M M, Mohammadi S S, Chiu H Y, Chu C H, Lee H Y and Lo C H 2013 Eocene-Oligocene post-collisional magmatism in the Lut-Sistan region, eastern Iran: Magma genesis and tectonic implications; Lithos 180-181 234-251.

Pang K N, Chung S L, Zarrinkoub M H, Mohammadi S S, Yang H M, Chu C H, Lee H Y and Lo C H 2012 Age, geochemical characteristics and petrogenesis of Late Cenozoic intraplate alkali basalts in the Lut-Sistan region, eastern Iran; Chem. Geol. 306-307 40-53.

Passchier C W and Trouw R A J 1996 Microtectonics; Berlin, Springer, 289p.

Paterson S R, Vernon R H and Tobish O T 1989 A review of criteria for the identification of magmatic and tectonic foliations in granitoids; J. Struct. Geol. 11 349-363.

Plissart G, Diot H, Monnier C, Mărunţiu M and Berger J 2012 Relationship between a syntectonic granitic intrusion and a shear zone in the Southern CarpathianBalkan area (Almăj Mountains, Romania): Implications for Late Variscan kinematics and Cherbelezu granitoid emplacement; J. Struct. Geol. 39 83-102.

Rasouli J, Ahadnejad V and Esmaeily D 2012 A preliminary study of the anisotropy of magnetic susceptibility (AMS) of Boroujerd granitoids, Sanandaj-Sirjan Zone, west Iran; Natural Sci. 4 91-105.

Richards J P, Spell T, Rameh E, Razique A and Fletcher T 2012 High Sr/Y magmas reflect arc maturity, high magmatic water content, and porphyry $\mathrm{Cu} \pm \mathrm{Mo} \pm \mathrm{Au}$ potential: Examples from the Tethyan arcs of central and eastern Iran and western Pakistan; Econ. Geol. 107 295-332.

Rochette P 1987 Magnetic susceptibility of the rock matrix related to magnetic fabric studies; J. Struct. Geol. 9 1015-1020.

Saccani E, Delavari M, Beccaluva L and Amini S 2010 Petrological and geochemical constraints on the origin of the Nehbandan ophiolitic complex (eastern Iran): Implication for the evolution of the Sistan Ocean; Lithos 117 209-228.

Sadeghian M, Bouchez J L, Nedelec A, Siqueira R and Valizadeh M V 2005 The granite pluton of Zahedan (SE Iran): A petrological and magnetic fabric study of a syntectonic sill emplaced in a transtensional setting; $J$. Asian Earth Sci. 25 301-327.

Saint-Blanquat (de) M and Tikoff B 1997 Development of magmatic to solid-state fabrics during syntectonic emplacement of the Mono Creek granite, Sierra Nevada batholith; In: Granite: From Segregation of Melt to Emplacement Fabrics (eds) Bouchez J L, Hutton D H W and Stephens W E, Kluwer Academic Publishers, Dordrecht, pp. 231-252.

Talbot J Y, Faure M, Chen Y and Martelet G 2005 Pullapart emplacement of the Margeride granitic complex (French Massif Central). Implications for the late evolution of the Variscan orogen; J. Struct. Geol. 27 16101629.

Tikoff B and Greene D 1997 Stretching lineations in transpressional shear zones: An example from the Sierra Nevada Batholith, California; J. Struct. Geol. 19 29-39.

Tikoff B and Teyssier C 1994 Strain modeling of displacement-field partitioning in transpressional orogens; J. Struct. Geol. 16 1575-1588.

Tirrul R, Bell I R, Griffis R J and Camp V E 1983 The Sistan suture zone of eastern Iran; Geol. Soc. Am. Bull. 94 134-150.

Turrillot P, Faure M, Martelet G, Chen Y and Augier R 2011 Pluton-dyke relationships in a Variscan granitic complex from AMS and gravity modelling. Inception of the extensional tectonics in the South Armorican Domain (France); J. Struct. Geol. 33 1681-1698.

Vegas N, Naba S, Bouchez J L and Jessell M 2008 Structure and emplacement of granite plutons in the 
Paleoproterozoic crust of Eastern Burkina Faso: Rheological implications; Int. J. Earth Sci. 97 1165-1180.

Vernant P, Nilforoushan F and Hatzfeld D et al. 2004 Present-day crustal deformation and plate kinematics in Middle East constrained by GPS measurements in Iran and northern Oman; Geophys. J. Int. 157 381-398.

Verner K, Zak J, Pertoldova J, Sramek J, Sedlak J, Trubac $\mathrm{J}$ and Tycova P 2009 Magmatic history and geophysical signature of a post-collisional intrusive center emplaced nearby a crustal-scale shear zone: The Plechý granite pluton (Moldanubian batholith, Bohemian Massif); Int. J. Earth Sci. 98 517-532.

Vernon R H 2000 Review of microstructural evidence of magmatic and solid-state flow; Vis Geosci. 5 1-23.

Vernon R H 2004 A Practical Guide to Rock Microstructure; UK, Cambridge University Press, 594p.

Walker R, Gans P, Allen M B, Jackson J, Khatib M M, Marsh N and Zarrinkoub M H 2009 Late Cenozoic volcanism and rates of active faulting in eastern Iran; Geophys. J. Int. 177 783-805.
Zak J, Verner K, Holub F V, Kabele P, Chlupacova M and Halodova P 2012 Magmatic to solid state fabrics, in syntectonic granitoids recording early Carboniferousorogenic collapse in the Bohemian Massif; J. Struct. Geol. $3627-42$.

Zarrinkoub M H, Chung S L, Chiu H Y, Mohammadi S S, Khatib M M and Lin I J 2010 Zircon U-Pb age and geochemical constraints from the northern Sistan suture zone on the Neotethyan magmatic and tectonic evolution in eastern Iran, Abstract to GSA Conference on 'Tectonic Crossroads: Evolving Orogens in Eurasia-Africa-Arabia', Turkey, 520p. Zarrinkoub M H, Chung S L, Mohammadi S S and Khatib M M 2011 Geochemistry, petrology and zircon U-Pb dating for Bibi Maryam granitoid, NE of Nehbandan, east of Iran; J. Econ. Geol. 3 15-27.

Zarrinkoub M H, Pang K N, Chung S L, Khatib M M, Mohammadi S S, Chiu H Y and Lee H Y 2012 Zircon U$\mathrm{Pb}$ ages and geochemical constraints on the origin of the Birjand ophiolite, eastern Iran; Lithos 154 392-405. 